\title{
Sistem informasi dan monitoring perkembangan janin berbasis android
}

\author{
Hilmy Abidzar Tawakal, Zaki Imaduddin, Irfan Prasetyo \\ STT Terpadu Nurul Fikri \\ email:hilmi.tawakal@gmail.com,zaki@nurulfikri.ac.id \\ Yudianto B. Saroyo \\ Medical Faculty University of Indonesia \\ email:yudibs@yahoo.com
}

\begin{abstract}
Pemantauan terhadap perkembangan janin akan memudahkan untuk mendeteksi adanya gejala pertumbuhan janin yang tidak normal. Pemantauan dilakukan dengan melakukan pengukuran dan perkiraan usia serta berat janin. Berat badan normal janin pada usia kehamilan tertentu mengacu pada data statistik kehamilan. Janin yang terlalu besar atau terlalu kecil dapat menimbulkan masalah yang cukup serius bagi proses persalinan maupun perkembangan bayi. Proses pemantauan perkiraan usia dan berat janin dapat dilakukan dengan mengukur tinggi fundus uteri maupun dengan mengukur biometri janin lewat citra USG (ultrasonografi). Guna memudahkan proses pemantauan dan pemberian informasi bagi ibu hamil, diperlukan sebuah sistem informasi yang dapat diakses dengan mudah. Sebuah sistem yang merekam perkembangan janin dan memberikan informasi yang mudah dipahami mengenai perkembangan janin bagi ibu hamil maupun petugas medis. Karenanya pengembangan aplikasi untuk perangkat bergerak bagi ibu hamil maupun petugas kesehatan (bidan) menjadi penting. Diharapkan dengan dikembangkannya aplikasi untuk perangkat bergerak, ibu hamil maupun tenaga medis menjadi mudah untuk melakukan proses pencatatan dan pengawasan perkembangan janin. Metode untuk mengukur perkembangan berat badan janin dilakukan dengan menggunakan pengukuran biometri janin melalui citra USG serta pengukuran tinggi fundus uteri. Aplikasi yang dikembangkan juga mampu menampilkan informasi grafis yang mudah dipahami mengenai perkembangan janin.
\end{abstract}

\section{Keywords}

Perkembangan Janin, Ultrasonografi (USG), Fundus uteri, Aplikasi perangkat bergerak

\section{PEndahuluan}

Mengetahui dan memantau perkembangan janin merupakan proses yang penting bagi ibu hamil dan petugas medis. Perkembangan janin yang terpantau akan memudahkan untuk mendeteksi adanya gejala janin tidak normal, sehingga dapat dilakukan tindakan medis sesegera mungkin. Perkembangan janin yang dipantau antara lain adalah prediksi berat serta usia janin.

Proses pemantauan yang selama ini ada adalah dengan aktif melakukan pengontrolan dan kunjungan ke tenaga medis seperti bidan dan dokter kandungan. Untuk daerah dengan jumlah tenaga medis yang terbatas, konsultasi dan kunjungan kepada petugas medis menjadi lebih sulit. Karenanya diperlukan sebuah sistem yang menanggulangi keterbataasan jarak tersebut, sehingga proses pemantauan tetap dapat dilakukan meskipun terpisah secara fisik.

Pengembangan aplikasi perangkat bergerak untuk ibu hamil memang telah banyak dilakukan, namun aplikasi yang dikembangkan hanya berupa panduan bagi ibu hamil dengan menampilkan artikel seputar perkembangan janin. Aplikasiaplikasi terkait ibu hamil yang terdapat pada android play store misalnya, berupa penyajian artikel dan informasi mengenai kehamilan seperti terlihat pada gambar 1 .

Belum ada satupun aplikasi yang memberikan informasi mengenai perkembangan janin yang sedang dikandung, serta

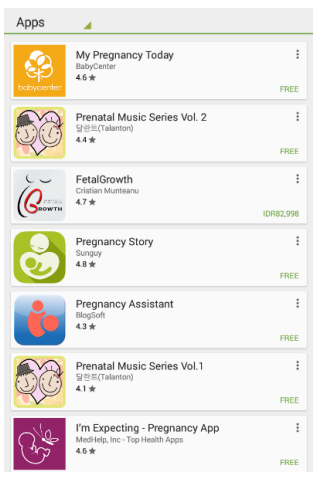

(a)

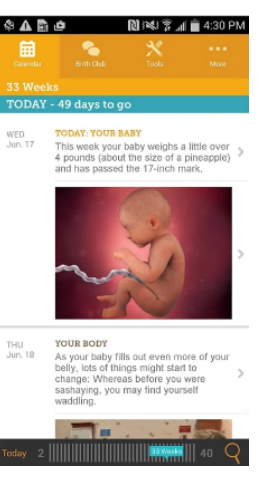

(b)

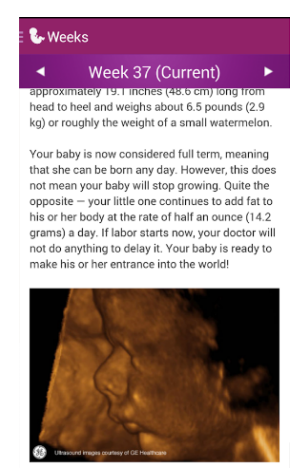

Fig. 1: (a) Hasil pencarian aplikasi perkembangan janin pada android play store (b) Contoh aplikasi android mengenai perkembangan janin

memudahkan berkonsultasi dengan tenaga medis. Pada penelitian ini dikembangkan aplikasi perangkat bergerak berbasis android yang memungkinkan pengguna mengetahui kondisi janin dengan menggunakan citra USG serta menggunakan metode pengukuran tinggi fundus uteri.

Menghitung biometri janin dan memprediksi usia serta 
berat janin dapat dilakukan dengan menggunakan beberapa pendekatan. Pendekatan yang dilakukan antara lain dengan menghitung biparetal diameter(BPD), occipito-frontal diameter (OFD), head circumference (HC) dan femur length $(F L)[1]$. Penelitian mengenai bagaimana menghitung biometri janin secara otomatis melalui citra USG juga telah dilakukan beberapa tahun belakangan ini. Pendekatan yang dilakukan oleh Carneiro[2] adalah dengan menerapkan boosting tree classifier, Vikram[3] menggunakan pendekatan active contour model, sedangkan Sandra[4] menggunakan deformable model. Dong[5] dan Imaduddin[6] menerapkan adaboost-RHT classifier untuk mendeteksi lokasi janin dan melakukan aproksimasi bentuk elips.

Menghitung tinggi fundus uteri sebagai parameter kesehatan perkembangan janin merupakan cara yang mudah untuk diterapkan. Metode prediksi berat janin dengan mengukur tinggi fundus uteri telah teruji cukup baik. Beberapa formula perhitungan telah diuji untuk mengetahui tingkat akurasi prediksi, antara lain formula yang diajukan oleh Johnson yang dikenal dengan formula Johnson. Formula yang diajukan oleh Johnson tersebut telah teruji dan telah dibandingkan dalam beberapa penelitian, antara lain dalam penelitian Watchree[7], dan Titisari[8]. Menurut penelitian Titisari[8] formula tersebut memiliki rata-rata perbedaan dengan berat sebenarnya adalah $156.1 \pm 107.3$ gram.

Formula perhitungan untuk mengukur janin penduduk Indonesia juga telah diajukan, terdapat formula yang diajukan oleh Siswosudarmo[8] yang dikenal dengan Formula Risanto. Melaui penelitiannya Risanto menemukan formula untuk menghitung perkiraan berat janin untuk penduduk Indonesia. Formula ini juga telah dilakukan pengujian oleh Titisari[8] dalam penelitiannya. Berdasarkan hasil penelitian [8] tersebut, rerata selisih antara prediksi berat janin dengan berat janin sebenarnya yang diukur saat persalinan adalah $100,8 \pm 86,1$ gram.

Meskipun tidak seakurat metode perhitungan dengan USG namun dari sisi kemudahan dan biaya jauh lebih baik. Selain itu selisih sebesar 100,8 $\pm 86,1$ gram menurut Risanto dapat diabaikan. Perangkat yang dibutuhkan untuk melakukan pengukuran tinggi fundus uteri hanya berupa penggaris berbentuk pita dan proses pengukurannya pun mudah. Bahkan jika tidak terdapat alat ukur, proses pengukuran juga dapat dilakukan dengan menggunakan jari sebagai acuan.

Pada penelitian ini dikembangkan aplikasi untuk perangkat bergerak yang mampu menampilkan dan mengelola informasi perkembangan janin. Informasi yang ditampilkan adalah informasi berat dan usia janin berdasarkan hasil pengukuran biometri janin melalui citra USG juga berdasarkan pengukuran tinggi fundus uteri.

Aplikasi yang dikembangkan menyajikan informasi dalam bentuk grafis mengenai perkembangan janin kedalam perangkat bergerak. Proses perhitungan dilakukan pada sisi perangkat pengguna (client), selanjutnya data hasil pengukuran juga disingkronisasikan ke-server pusat data untuk diteruskan kepada petugas kesehatan. Rancangan keseluruhan sistem dapat dilihat pada gambar 2

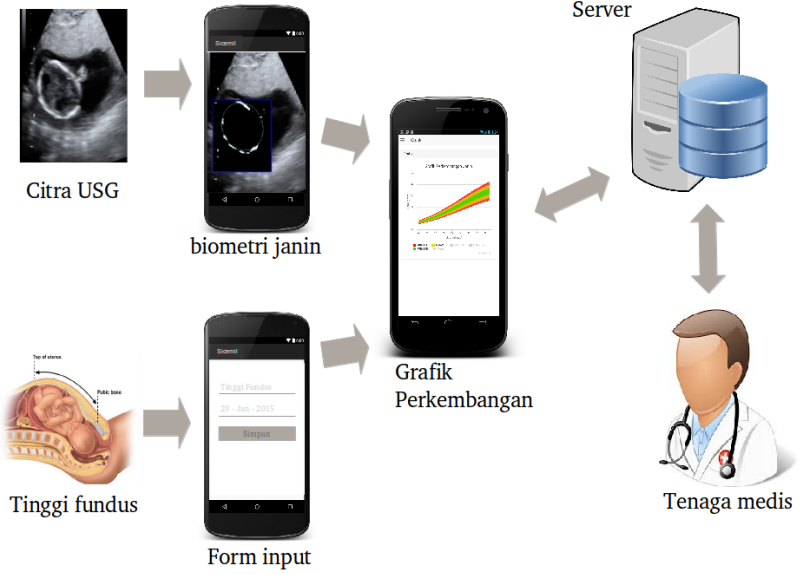

Fig. 2: Rancangan aplikasi sistem informasi perkembangan janin berbasis mobile

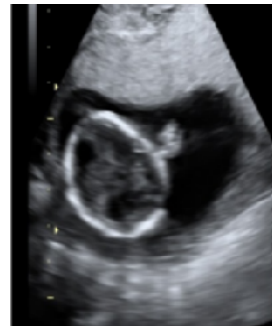

(a)

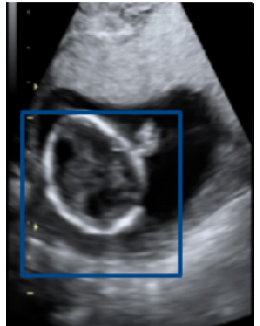

(b)

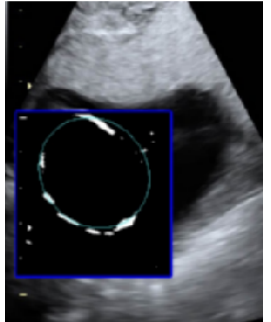

(c)
Fig. 3: (a) Cita USB masukan, (b) deteksi lokasi janin, (c) aproksimasi bentuk geometri janin. sumber:Imaduddin [6]

\section{METODE PENGUKURAN PERKEMBANGAN JANIN}

\section{A. Biometri janin dari citra USG}

Penelitian ini menerapkan proses pengukuran biometri janin dari citra USG dengan menggunakan pendekatan yang dilakukan Imaduddin[6]. Proses pengukuran dilakukan secara otomatis dengan melakukan serangkaian algoritma pengolahan citra terhadap citra USG. Citra hasil USG yang akan diukur biometrinya terlebih dahulu akan menjalani serangkaian proses. Pada gambar 3 digambarkan alur pengolahan citra USG untuk mendapatkan nilai biometri janin serta prediksi usia dan berat janin. Tahapan proses tersebut adalah sebagai berikut:

1) Mendeteksi lokasi janin

2) Melakukan aproksimasi bentuk geometri

3) Menghitung prediksi usia dan berat janin

1) Deteksi lokasi janin: Pendekatan yang dilakukan dalam mendeteksi lokasi janin adalah dengan pendekatan pemelajaran mesin (machine learning). Pada pendekatan ini dibutuhkan data citra janin untuk proses pembelajaran sistem. Citra yang disiapkan adalah citra yang mengandung obyek yang akan dideteksi (citra positif) dan citra yang tidak mengandung objek (citra negatif). Kedua jenis citra ini digunakan untuk 
proses pembelajaran sistem sehingga mendapatkan parameterparameter dan model yang mampu membedakan antara objek dan non-objek.

Untuk mengenali ciri dari masing-masing citra dilakukan proses ekstraksi ciri (fitur). Jika informasi dari tiap citra hanya berdasarkan informasi nilai tiap piksel maka proses perhitungan akan sangat besar sehingga membutuhkan sumberdaya yang besar pula. Kebutuhan suber daya komputasi yang besar akan menghambat penerapan sistem pada perangkat bergerak yang memiliki sumber daya terbatas. Karenanya dengan mengambil ciri (fitur) tertentu saja dari citra, proses perhitungan menjadi lebih sederhana dibandingkan jika dilakukan untuk tiap piksel.

Proses pemilihan fitur merupakan elemen yang menentukan dalam proses pengenalan objek. Pemilihan fitur yang tidak tepat akan mengakibatkan proses pengenalan menjadi tidak sesuai. Citra USG yang digunakan dalam penelitian ini adalah citra grayscale dimana warna bukanlah fitur yang dapat digunakan, karenanya pada penelitian ini fitur yang digunakan adalah fitur haar-like. Fitur haar-like adalah fitur yang pernah diterapkan oleh Papageorgiou[9] sebagai framework untuk deteksi objek, yaitu dengan menghitung selisih antar citra dengan serangkaian bentuk fitur. Contoh bentuk fitur haar-like adalah seperti pada gambar 5 .

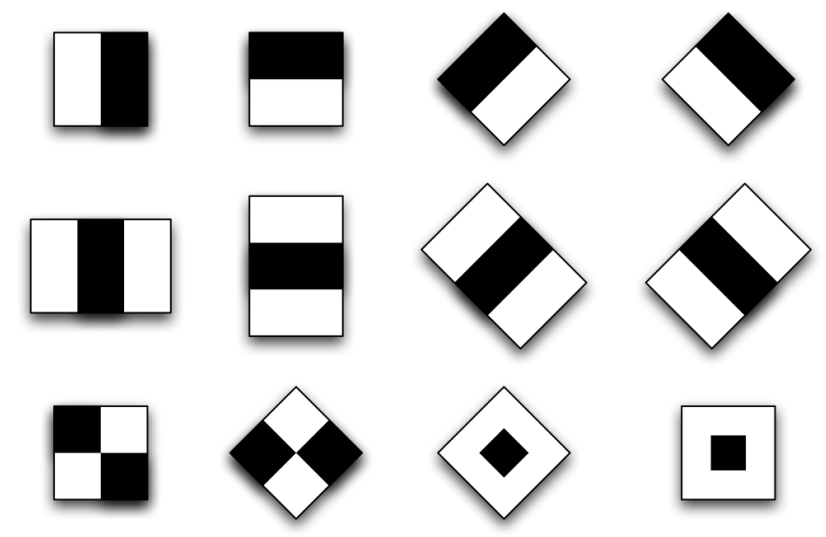

Fig. 4: Bentuk-bentuk fitur haar-like. sumber: Karl Berggren [10]

Penggunaan fitur haar-like juga dikarenakan proses perhitungan yang cepat dan ringan dengan menggunakan metode integral images. Proses perhitungan integral images memungkinakan hasil perhitungan sebelumnya untuk digunakan berulang kali pada proses perhitungan sebelumnya. Pendekatan ini menjadikan proses perhitungan menjadi lebih efisien. Ilustrasi proses perhitungan dengan menggunakan metode integral images adalah seperti pada gambar

Pada tiap jenis citra tidak semua fitur haar-like digunakan untuk mendapatkan informasi dari citra. Fitur-fitur tersebut diseleksi untuk mendapatkan fitur yang memberikan nilai perbedaan yang signifikan antara objek dan bukan objek. Metode yang diterapkan untuk melakukan pemilihan fitur adalah dengan metode boost-ing, yaitu metode yang meng-

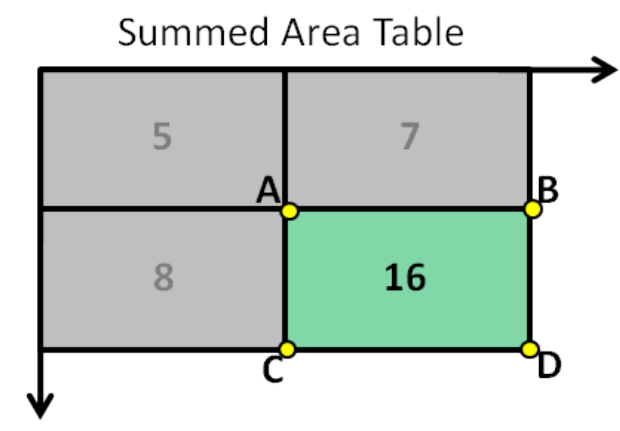

Fig. 5: Menghitung fitur pada suatu area dengan menggunakan perhitungan area sebelumnya yang telah dilakukan

$\left(\mathrm{x}^{\prime}, \mathrm{y}^{\prime}\right)=\mathrm{s}($ A $)+\mathrm{s}($ D) $-\mathrm{s}($ B $)-\mathrm{s}(\mathrm{C})$ ).

sumber:http://bitsearch.blogspot.co.id/

gabungkan beberapa fitur yang memiliki nilai klasifikasi rendah weak classifier untuk mendapatkan fitur klasifikasi yang lebih tinggi strong classifier. Metode boosting yang digunakan adalah metode adaptive boosting (AdaBoost). Menurut Chengxiong[11] metode AdaBoost terbukti mampu memilih fitur-fitur apa saja yang akan memisahkan antara objek dan non-objek.

Proses pelatihan dengan menggunakan citra positif (citra dengan objek janin) dan citra negatif (citra tanpa objek janin) dilakukan untuk mendapatkan parameter pada model yang dapat membedakan antara objek janin dengan non-janin (classifier) berdasarkan fitur haar-like. Setelah didapatkan parameter classifier, proses untuk membedakan antara objek dengan non-objek adalah dengan menggunakan klasifikasi bertingkat (cascade classifier).

2) Aproksimasi bentuk janin: Hasil dari proses pendeteksian lokasi janin adalah letak objek yang diduga janin. Area yang diduga objek janin inilah yang kemudian dilakukan proses aproksimasi bentuk dan ukurannnya. Menurut penelitian [Imaduddin], melakukan pendeteksian lokasi janin mampu mereduksi noise sehingga mampu meningkatkan proses aproksimasi. Proses aproksimasi bentuk dilakukan dengan pendekatan IRHT (Iterative Randomize Hough Transform) yang merupakan algoritma untuk aproksimasi bentuk elips.

Langkah langkah dalam melakukan aproksimasi bentuk elips dengan menggunakan metode IRHT adalah dengan memilih secara acak 5 piksel dari keseluruhan piksel yang akan diaproksimasi, selanjutnya dari 5 piksel ini akan dicari bentuk persamaan elipse (persamaan 1) untuk mendapatkan kandidat bentuk elips (Gambar 6).

$$
x^{2}+y^{2}-U\left(x^{2}-y^{2}\right)-V 2 x y-R x-S y-T=0
$$

Persamaan tersebut diturunkan menjadi[12]:

$$
\begin{aligned}
& x=\frac{S V+R+R U}{2\left(1-U^{2}-V^{2}\right)} \\
& y=\frac{R V+S+S U}{2\left(1-U^{2}-V^{2}\right)}
\end{aligned}
$$




$$
\begin{gathered}
a=\sqrt{\frac{2 T+x_{0} R+y_{0} S}{2\left(1-\sqrt{U^{2}+V^{2}}\right)}} \\
b=\sqrt{\frac{2 T+x_{0} R+y_{0} S}{2\left(1+\sqrt{U^{2}+V^{2}}\right)}} \\
\theta=\frac{1}{2} \arctan \frac{V}{U}
\end{gathered}
$$

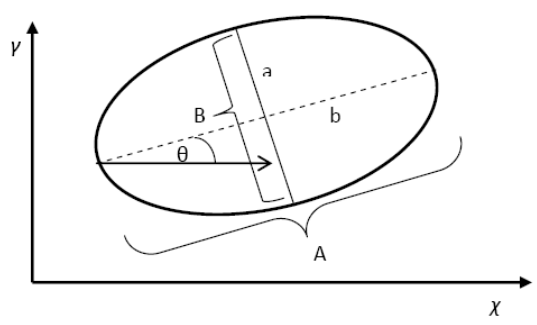

Fig. 6: Parameter elipse. sumber: Imaduddin [6]

Setelah didapatkan kandidat elips, ulangi langkah tersebut untuk mendapatkan banyak kandidat elips, yang akhirnya akan dipilih elipse dengan irisan terbanyak dari beberapa kandidat elipse.

3) Perhitungan Usia dan Berat janin: Setelah didapatkan prediksi bentuk organ janin, langkah selanjutnya adalah mengukur dan menghitung usia janin. Prediksi usia dan berat janin dihitung dengan menggunakan besar lingkar kepala janin (BPD). Berdasarkan penelitian Hadlock [13] perhitungan usia dapat dengan menggunakan beberapa acuan, namun yang cukup akurat adalah dengan menggunakan lingkar kepala janin. Pada penelitian ini hasil prediksi lingkar kepala janin digunakan untuk menhitung prediksi berat badan janin.

\section{B. Pengukuran tinggi fundus uteri}

Pengukuran tinggi fundus uteri dilakukan dengan cara mengukur langsung tinggi fundus uteri pada perut ibu hamil. Tinggi fundus uteri diukur dari tulang kemaluan ibu hamil hingga ujung akhir dari rahim (fundus uteri). Ilustrasi mengenai pengukuran tinggi fundus uteri dapat dilihat pada gambar 7 . Teknik pengukuran sangat sederhana, yaitu dengan menggunakan alat ukur berbentuk pita. Jika tidak ditemukan alat ukur, maka pengukuran juga dapat dilakukan dengan menggunakan jari sebagai acuan (gambar 8).

\section{PENERAPAN PADA APLIKASI MOBILE}

\section{A. Implementasi Pengukuran Janin}

Proses penerapan algoritma perhitungan biometri janin berdasarkan citra USG pada perangkat bergerak dibagi menjadi dua tahap. Tahap pertama adalah proses pelatihan atau pembelajaran dengan menggunakan citra positif dan negatif. Proses ini dilakukan untuk mendapatkan model yang membedakan antara objek janin dan selain janin. Tahap pertama ini membutuhkan waktu dan sumberdaya komputasi yang besar, sehingga

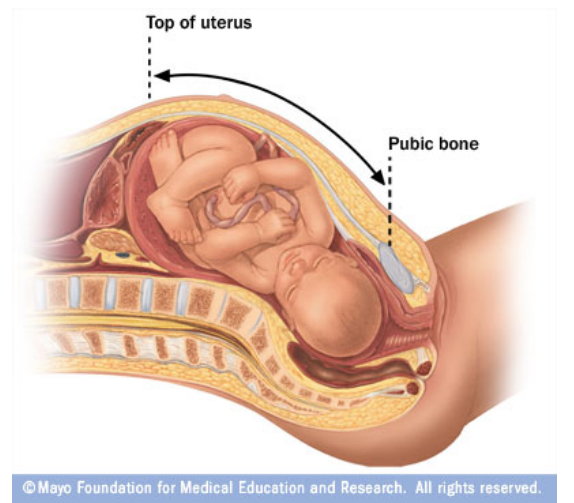

Fig. 7: Pengukuran tinggi fundus uteri. sumber:http://www.mayoclinic.org/
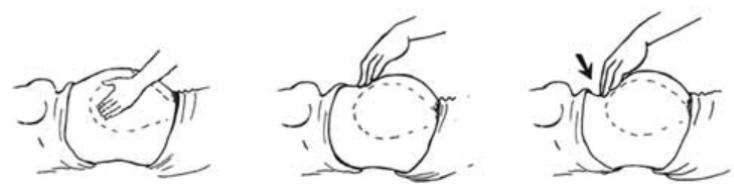

(a)

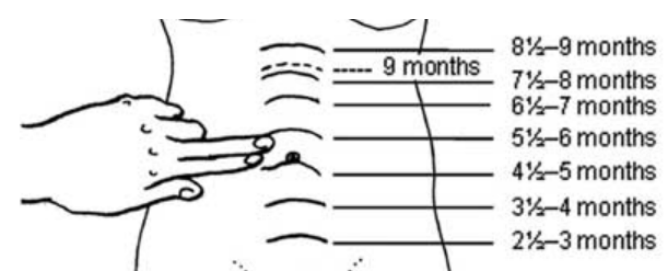

(b)

Fig. 8: (a) Persiapan pengukuran tinggi fundus, (b) mengukur tinggi fundus dengan jari. sumber:http://www.open.edu/

harus dilakukan di komputer dengan sumberdaya yang cukup besar.

Tahap kedua adalah proses deteksi dan aproksimasi bentuk janin pada perangkat bergerak. Deteksi lokasi janin dilakukan dengan membaca citra USG yang didapat melalui kamera perangkat maupun proses unggah. Citra tersebut dihitung nilai fiturnya untuk kemudian dilakukan proses deteksi mengunakan model yang sebelumnya telah dilatih dengan metode cascade classifier. Hasil dari proses ini adalah lokasi janin pada citra USG. Selanjutnya berdasarkan lokasi janin tersebut dilakukan prediksi bentuk janin dengan menggunakan metode IRHT. Hasil prediksi bentuk geometri tersebut kemudian diukur nilai diameter untuk menghitung berat dan usia janin.

Penerapan algoritma pendeteksi janin dilakukan dengan menggunakan bahasa $\mathrm{C}++$ serta membutuhkan pustaka opencv. Untuk menerapkannya kode tersebut pada aplikasi android maka digunakan NDK (Native Development Kit) dimana pengembang dapat menyertakan kode dengan bahasa selain java (seperti $\mathrm{C}++$ ) kedalam aplikasi android.

Citra USG yang digunakan untuk pengukuran adalah citra 
yang didapatkan melalui kamera device. Pengguna melakukan proses pengambilan gambar melalui kamera perangkat pada objek foto maupun dari monitor alat USG. Selain itu citra USG juga dapat diperoleh dengan melakukan proses unggah file gambar USG kedalam perangkat.

Proses untuk mendapatkan data hasil pengukuran tinggi fundus uteri dilakukan secara manual. Sebelumnya pengguna melakukan pengukuran secara manual, baik dengan alat ukur maupun dengan jari. Pengguna kemudian melakukan proses input data hasil pengukuran ini kedalam perangkat dengan menggunakan form yang disediakan aplikasi.

\section{B. Grafik perkembangan janin}

Guna memudahkan proses pemantauan, maka hasil pengukuran perlu ditampilkan dalam bentuk grafik dan dibandingkan dengan grafik pertumbuhan janin yang normal. Proses pemantauan dengan grafik akan memudahkan untuk mengetahui bukan hanya sekedar berat janin, namun apakah berat janin tersebut masih dalam batas normal atau tudak. Terkadang ukuran berat janin bertambah, namun pertambahannya tidak cukup bagus sehingga janin berada pada batas bawah pertumbuhan janin. Kasus seperti ini sulit untuk dideteksi tanpa menggunakan grafik, sebaliknya dengan menggunakan grafik indikasi perkembangan janin terhambat dapat segera tertangani.

Acuan pertumbuhan janin yang normal didapat dari data statistik perkembangan janin. Data statistik tertentu didapat dari berbagai penelitian seperti yang terdapat pada penelitian Rafael [14]. Penelitian tersebut menunjukkan nilai persentil perkembangan janin dari berbagai ras dan negara. Gambar 9 menunjukkan tabel nilai persentil dari perkembangan janin yang terdapat pada penelitian Rafael tersebut.

\begin{tabular}{|c|c|c|c|c|c|c|c|c|c|c|}
\hline & $n$ & $\begin{array}{l}\text { Term births } \\
\text { (37-42 weeks, } x)\end{array}$ & $\begin{array}{l}\text { Median } \\
\text { matemal } \\
\text { height } \\
\text { (cm, IR })\end{array}$ & $\begin{array}{l}\text { Median } \\
\text { materanal } \\
\text { weighte" } \\
\text { (kg, (QR })\end{array}$ & $\begin{array}{l}\text { Bithweight } \\
\text { reported oflyn in } \\
\text { full 100sg" (x) }\end{array}$ & 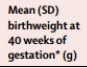 & $\begin{array}{l}\text { Coefficient of } \\
\text { variationt (x) }\end{array}$ & $\begin{array}{l}\text { Adverse } \\
\text { perinatal } \\
\text { eventst( }(x)\end{array}$ & Deathss (x) & $\begin{array}{l}\text { SGA } \\
\text { accordingto } \\
\text { Hadlock"(x) }\end{array}$ \\
\hline \multicolumn{11}{|l|}{ Africa } \\
\hline Algeria & 14775 & $95 \%$ & $162(159-165)$ & $72(65-80)$ & $77 \times$ & $3511(467)$ & $13 \cdot 3 \%$ & $4.0 \%$ & $2.0 x$ & $14 \%$ \\
\hline Angola & 3358 & $59 \%$ & $160(155-165)$ & $62(56-69)$ & $69 \%$ & $3202(463)$ & $145 \%$ & $9.6 \%$ & $2.4 \%$ & ${ }_{19 \%}$ \\
\hline Congo & 8354 & $84 x$ & 156(152-1616) & $59(55-65)$ & $49 \%$ & 3091(440) & $142 \%$ & $5.7 \%$ & $2.8 \mathrm{x}$ & $35 \%$ \\
\hline Kenya & 2658 & $93 \%$ & 158(154-163) & 65 (660-73) & ${ }^{83 x}$ & $3176(448)$ & $141 \%$ & $5.2 x$ & $2 \cdot 3 \times$ & $32 x$ \\
\hline Niger & 7985 & $96 x$ & $160(158-165)$ & 65 (58-73) & $51 \times$ & 3103(429) & 138\% & $46 \mathrm{x}$ & $3.1 \times$ & $42 x$ \\
\hline Nigeria & 7567 & $88 \%$ & $160(156-165)$ & $73(64-83)$ & $97 \times$ & $3298(498)$ & $15.1 \%$ & $10.1 \%$ & $3.9 \%$ & $22 x$ \\
\hline Uganda & 10457 & 916 & $159(155-164)$ & $64(58-72)$ & $95 \%$ & $3336(456)$ & $13.7 \%$ & $4.1 \%$ & $2.4 \%$ & $16 \%$ \\
\hline \multicolumn{11}{|c|}{ Latin America } \\
\hline Argentina & 7074 & $91 \%$ & $159(155-163)$ & $72(65-80)$ & $26 \times$ & $3494(428)$ & $12: 2 \%$ & $2.8 \mathrm{x}$ & $0.9 x$ & $15 \%$ \\
\hline Brazil & 4847 & ${ }_{92 x}$ & 158.5(154-163) & $68(61-75)$ & $10 x$ & 3331 (439) & ${ }^{1322}$ & $6.0 x$ & ${ }^{1.5 \%}$ & $25 \times$ \\
\hline cuba & 12489 & $95 \%$ & $159(155-163)$ & $68(62-76)$ & $34 x$ & $3374(446)$ & $13.2 \%$ & $2.2 \%$ & 1.14 & $22 \%$ \\
\hline Ecuador & 11397 & $93 \%$ & $154(150-159)$ & $65(59-72)$ & 53\% & $3222(422)$ & 13.1\% & $5.4 \%$ & 136 & 316 \\
\hline Mexico & 19394 & $91 \%$ & $156(152-160)$ & $69(62-76)$ & $47 \%$ & $3288(432)$ & 13.1\% & $2.5 \%$ & $1.0 \%$ & $24 \%$ \\
\hline Nicaragua & 5576 & $93 \%$ & $155(151-158)$ & $66(60-73)$ & $55 \%$ & $3214(444)$ & $12.9 \%$ & $2.2 \%$ & ${ }^{1.36}$ & $24 \%$ \\
\hline Paraguay & 3060 & ${ }_{916}$ & $158(155-161)$ & $71(65-79)$ & $37 \times$ & $3506(441)$ & $12.6 \%$ & 4.1\% & $1.5 \times$ & $14 \%$ \\
\hline & 13692 & 926 & 154(150-158) & 66 66(61-73) & $27 \times$ & 3456 (4422) & $12.2 \%$ & $5.3 \times$ & $1.4 x$ & 15\% \\
\hline \multicolumn{11}{|c|}{ 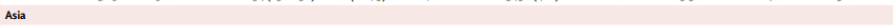 } \\
\hline Cambodia & 5362 & 93\% & $155(151-158)$ & $58(54-64)$ & $91 \mathrm{x}$ & $3126(402)$ & $12.9 \%$ & $6.6 \%$ & ${ }_{1.96}$ & $47 \%$ \\
\hline China & 14286 & 95\% & $159(156-162)$ & $66(61-72)$ & $64 x$ & $3410(411)$ & $12 \cdot 1 \%$ & $1.2 x$ & $0.3 \times$ & $21 \times$ \\
\hline India & 23960 & $78 \%$ & $152(150-155)$ & $55(50-59)$ & $78 \%$ & $2790(396)$ & $142 \%$ & $8.8 \mathrm{x}$ & $41 \mathrm{x}$ & $60 \%$ \\
\hline Japan & 3204 & 95\% & $158(154-162)$ & $62(57-67)$ & $2 \times$ & $3160(357)$ & $11 \cdot 3 \%$ & $44 \mathrm{x}$ & $0.1 \mathrm{x}$ & 44\% \\
\hline Nepal & 8268 & $88 \%$ & $150(148-153)$ & $58(52-63)$ & $87 \times$ & $3016(448)$ & $149 \%$ & $6.6 \%$ & $2: 16$ & $50 \%$ \\
\hline & 10533 & 92\% & $155(152-158)$ & $60(54-68)$ & $48 \%$ & $3052(408)$ & $13.4 \%$ & $3.7 \%$ & $1.6 \%$ & $51 \%$ \\
\hline Srilanka & 14708 & $93 \%$ & $154(150-158)$ & $60(54-67)$ & $30 \%$ & $3079(399)$ & $130 \%$ & $1.8 \%$ & $0.5 \%$ & $47 \%$ \\
\hline Thailand & 9334 & $90 \%$ & $156(152-160)$ & $66(60-73)$ & $14 \times$ & $3237(412)$ & $12.7 \%$ & $3.0 \%$ & $0.4 \times$ & $30 x$ \\
\hline Vietram & 13167 & 95\% & $155(152-159)$ & $60(55-65)$ & ${ }_{93} \mathrm{x}$ & $3255(385)$ & $11.8 \%$ & 1.1.16 & $0.2 \mathrm{x}$ & $36 x$ \\
\hline
\end{tabular}

Fig. 9: Nilai persentil berat janin untuk berbagai negara di dunia. sumber: Rafael [14]

Berdasarkan data persentil pada tersebut, penelitian ini membuat grafik acuan pertumbuhan janin. Pada penelitian Rafael tersebut memang tidak terdapat negara Indonesia, namun untuk penduduk Indonesia dapat menggunakan negara dengan ras yang masih serumpun seperti vietnam dan thailand. Hal ini dilakukan karena sampai saat ini belum ada penelitian untuk menghitung nilai statistik pertumbuhan janin untuk penduduk Indonesia.

Perhitungan dan pembuatan grafik persentil dilakukan dengan menggunakan formula yang diajukan oleh Hadlock [13]. Pada formula tersebut dihitung besar persentil untuk tiap minggu usia janin berdasarkan nilai rerata berat janin usia 40 minggu dan standar deviasi. Pada penelitian ini, nilai berat rata-rata janin usia 40 minggu serta standar deviasi didapat dari penelitian Rafael [14]. Bentuk grafik hasil perhitungan formula Hadlock dapat dilihat pada gambar 10

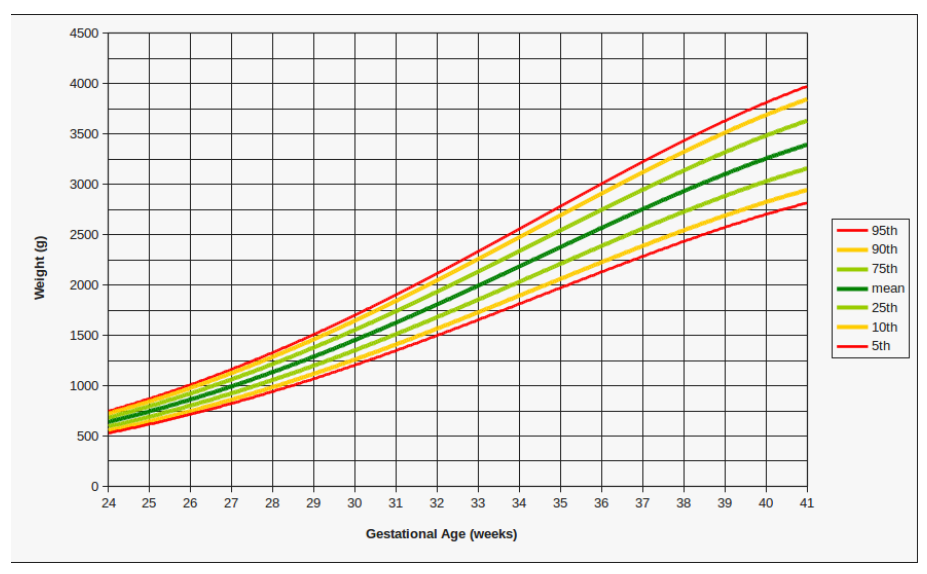

Fig. 10: Grafik hasil perhitungan formula Hadlock [13]

Menampilkan grafik dalam perangkat bergerak seperti android dapat dilakukan dengan beberapa pendekatan, pada penelitian ini proses untuk menampilkan grafik dilakukan dengan membuat grafik dalam bentuk javascript dan menampilkan dalm bentuk web view pada android. Pustaka javascript yang digunakan untuk membuat grafik pada peneitian ini adalah pustaka highchart.

\section{Sistem pengolahan data}

Selain untuk informasi pribadi, data hasil pengukuran juga diperlukan untuk kegiatan konsultasi dengan tenaga medis terkait seperti dokter kandungan atau bidan. Karenanya diperlukan mekanisme untuk berbagi data. Pada penelitian ini dikembangkan sistem pada server yang berfugsi untuk menerima data dari pengguna untuk kemudian dibagi kepada pengguna lain yang diberikan kewenangan.

Proses komunikasi antara perangkat dengan sistem pada server dilakukan dengan menggunakan teknologi web service. Teknologi web service yang digunakan adalah teknologi RestFull web service. Guna menjaga keamanan data maka proses komunikasi antara perangkat dengan server dilakukan dengan menggunakan mekanisme penambahan kode token.

\section{Pengujian Sistem}

Eksperimen pada sistem dilakukan untuk menguji dan mengetahui unjuk kerja dari sistem. Terdapat beberapa tahapan 
pengujian yang dilakukan terhadap aplikasi yang telah dibuat. Pengujian pertama adalah pengujian kemampuan perhitungan biometri janin secara otomatis. Pada pengujian kemampuan perhitungan otomatis ini dibandingkan antara hasil perhitungan sistem dengan hasil perhitungan yang dilakukan oleh pakar. Pengujian selanjutnya adalah pengujian fungsionalitas aplikasi. Pada pengujian ini akan diuji bagaimana fungsionalitas tiap fitur pada aplikasi yang dikembangkan.

\section{A. Pengujian pengukuran biometri janin}

Berdasarkan hasil perbandingan antara hasil perhitungan secara otomatis dengan pakar diketahui bahwa sistem yang dikembangkan memiliki tingkat kesamaan yang cukup tinggi dengan pakar. Kesalahan prediksi sistem adalah 0.005 dengan koefisien korelasi sebesar 0.999 .

\section{B. Pengujian fungsionalitas sistem}

Hasil penerapan pada perangkat bergerak berbasis android menunjukkan bahwa rancangan sistem mampu berjalan dengan baik untuk semua fitur yang dirancang. Fitur utama untuk menampilkan grafik perkembangan janin pada perangkat android juga bekerja dengan baik. Hasil implementasi pada perangkat bergerak berbasis android dapat dilihat pada gambar 11

\section{KESIMPULAN}

Berdasarkan hasil pengujian yang dilakukan terhadap sistem yang dikembangkan, proses pengukuran secara otomatis terhadap biometri janin memiliki tingkat kesalahan yang cukup kecil yakni hanya 0.005 . Hasil pengujian aplikasi juga menunjukkan bahwa sistem yang dikembangkan juga berjalan sesuai dengan fungsinya. Dengan hasil yang cukup baik ini diharapkan ada penelitian lanjutan yang mengintegrasikan sistem dengan rumah sakit atau rumah bersalin. Selain dari sisi perangkat lunak, pengembangan perangkat keras pendukung juga sangat diperlukan. Salah-satunya adalah mengembangan alat USG yang portable dan dapat terhubung langsung dengan smartphone

\section{REFERENCES}

[1] R. Sanders and A. James, The Principles and Practice of Ultrasonorraphy in Obstetrics and Gynecology, 3rd edition. Connecticut: AppletonCentury-Crofts, 1985.

[2] G. Carneiro, B. Georgescu, S. Good, and D. Comaniciu, "Detection and measurement of fetal anatomies from ultrasound images using a constrained probabilistic boosting tree," IEEE TRANSACTIONS ON MEDICAL IMAGING, vol. 27, no. 5, pp. 1342-1355, 2008 (September 13).

[3] V. Chalana, T. C. W. III, D. R. Cyr, D. R. Haynor, and Y. Kim, "Automatic fetal head measurements from sonographic images," Academic Radiology, vol. 3, no. 8, pp. 628-635, 1996.

[4] S. M. Jardim and M. A. Figueiredo, "Segmentation of fetal ultrasound images," Ultrasound Med Biol, vol. 31, no. 2, pp. 243-250, 2005.

[5] Dong.Ni, Yong.Yang, Shengli.Li, Jing.Qin, Shuyuan.Ouyang, Tianfu.Wang, and Pheng.Ann.Heng, "Learning based automatic head detection and measurement from fetal ultrasound images via prior knowledge and imaging parameters," 10th International Symposium on Biomedical Imaging: From Nano to Macro IEEE, pp. 772-775, April 2013.

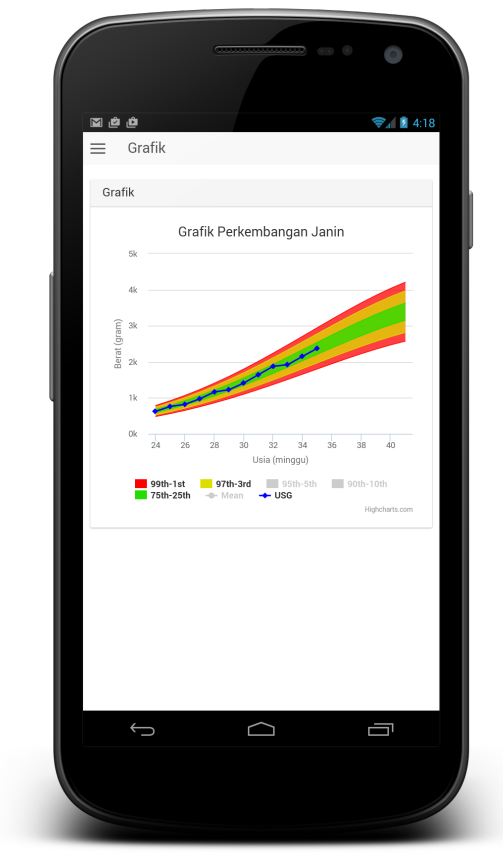

(a)

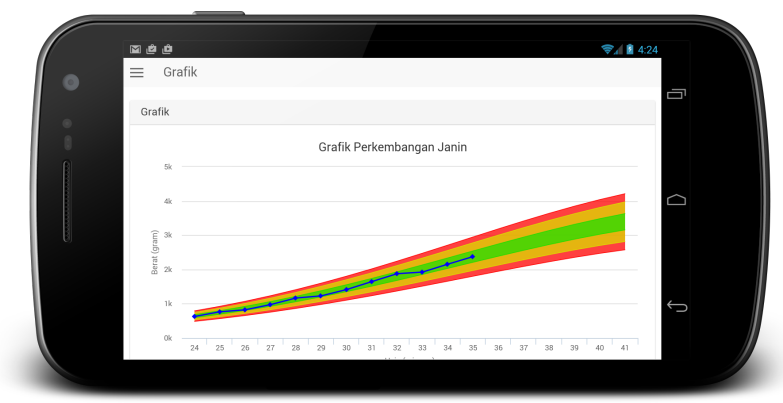

(b)

Fig. 11: Hasil implementasi pada perangkat berbasis android (a) posisi tegak dan (b) posisi landscape

[6] Z. Imaduddin, M. Akbar, H. Tawakal, I. Satwika, and Y. Saroyo, "Automatic detection and measurement of fetal biometrics to determine the gestational age," in Information and Communication Technology (ICoICT ), 2015 3rd International Conference on, pp. 608-612, May 2015.

[7] W. Numprasert, "A study in johnsons formula:fundal height measurement for estimation of birth weight," A U J.T., pp. 15-20, 2004.

[8] H. I. Titisari and R. Siswosudarmo, "Risantos formulas is more accurate in determining estimated fetal weight based on maternal fundal height," Indones J Obstet Gynecol, pp. 149-150, 2013.

[9] Papageorgiou.C, Oren.M, and Poggio.T, "A general framework for object detection," International Conference on Computer Vision, 1998.

[10] K. B. . P. Gregersson, "Camera focus controlled by face detection on gpu," MSc Thesis Lund University, 2008.

[11] Chengxiong.Ruan, Q. Ruan, and X. Li, "Real adaboost feature selection for face recognition," International Conference on Signal Processing Proceedings, pp. 1402-1405, 2010.

[12] Xu.L, Oja.E, and Kultanen.P, "A new curve detection method: Random- 
ized hough transform (rht)," Journal Pattern Recognition, vol. 11, no. 5, pp. 331-338, 1990.

[13] F. P. Hadlock, R. Harrist, R. S. Sharman, R. L. Deter, and S. K. Park, "Estimation of fetal weight with the use of head, body, and femur measurementsa prospective study," American Journal of Obstetrics and Gynecology, vol. 151, no. 3, pp. 333 - 337, 1985.

[14] R. T. e. a. Mikolajczyk, "A global reference for fetal-weight and birthweight percentiles," The Lancet, pp. 1855 - 1861, 2011. 